\title{
Analisis Sikap Pegawai terhadap Perilaku Pelayanan Publik (Studi Kasus di BP2T Kabupaten Sragen dan Kabupaten Sidoarjo)
}

\author{
Puji Winarni ${ }^{1}$, Ma'mun Sarma ${ }^{2}$, Darwis S. Gani ${ }^{3}$, Soenarmo Hatmodjosoewito ${ }^{4}$ \\ ${ }^{1}$ Pusat Penelitian Sistem Mutu dan Teknologi Pengujian (P2SMTP)- LIPI, Jakarta \\ ${ }^{2}$ Departemen Manajemen Fakultas Ekonomi dan Manajemen Kampus IPB Darmaga Bogor 16680 \\ ${ }^{3}$ Departemen Sains Komunikasi dan Pengembangan Masyarakat Fakultas Ekologi Manusis IPB Bogor 16680 \\ ${ }^{4}$ Kementerian Pertanian Jakarta
}

\begin{abstract}
The implementation of Quality Management System (ISO 9001) by BP2T in both Sidoarjo and Sragen Districts has been considered successful in transforming the existing paradigm of service which had been criticized as being irresponsive, untrustworthy, and not oriented toward public interest. The existence of service culture oriented toward public interest has been in doubt due to the prevailing perception that quality culture has not developed within the Government's bureaucratic environment. This study has aimed at: 1) analyzing the Government employers' attitudes toward the implementation of ISO 9001: 2) explaining the impacts of the attitudes on the service behaviors among those Government employers who are more responsive toward the public interest. The study shows that there has been a significant positive attitude among the employers toward the implementation of ISO 9001 which has, in turn, positively correlated with their responsive service to the public.
\end{abstract}

Key words: ISO 9001, employees' attitudes and behaviors, BP2T, Government employers

Abstrak

Penerapan Sistem Manajemen Mutu ISO 9001 yang telah berlangsung cukup lama di BP2T Kabupaten Sragen dan Kabupaten Sidoarjo dianggap sukses dalam mengubah paradigma pelayanan birokrasi yang selama ini tidak responsif, tidak dapat dipercaya dan tidak berorientasi kepada masyarakat. Budaya pelayanan yang berorientasi kepada masyarakat masih diragukan keberadaannya, terutama budaya mutu yang dianggap bukan merupakan budaya yang tumbuh di birokrasi pemerintahan. Tujuan penelitian ini adalah: (1) menganalisa sikap pegawai terhadap penerapan SMM ISO 9001 dan (2) bagaimana pengaruh sikap tersebut terhadap perilaku pegawai pada pelayanan yang responsif kepada masyarakat. Hasil penelitian menunjukkan sikap positif pegawai terhadap penerapan SMM ISO 9001 dan sikap tersebut berkorelasi positif terhadap perilaku pegawai dalam memberikan pelayanan yang responsif kepada masyarakat.

Kata Kunci: SMM ISO 9001, sikap dan perilaku, BP2T, pegawai pemerintah

\section{Pendahuluan}

Kualitas pelayanan publik di era otonomi daerah belum dapat ditingkatkan secara signifikan sejalan dengan peningkatan pendapatan daerah dan beban masyarakat. Pelayanan publik belum berhasil mewujudkan sistem administrasi pelayanan yang memberikan kesetaraan antara pemberi layanan (pemerintah daerah) dengan masyarakat yang dilayani (Priyono, 2006). Pemerintah daerah provinsi, kabupaten dan kota bahkan belum mampu memberikan pelayanan publik dengan kualitas standar pelayanan minimum. Disisi lain, masyarakat belum memahami secara pasti sta-

\footnotetext{
${ }^{1}$ Korespondensi Penulis. Tlp: 08161829411

E-mail: p_winarni@yahoo.com.sg
}

ndar pelayanan yang seharusnya diterima sesuai dengan prosedur pelayanan publik yang dibakukan. Strategi pelayanan prima sebagaimana diterapkan oleh beberapa pemerintah daerah sebagai upaya pelaksanaan UndangUndang Pelayanan Publik nomor 25 tahun 2009 belum dapat dipenuhi oleh pemerintah daerah dalam waktu yang pendek (Widodo, 2005).

Pelayanan prima yang diterapkan organisasi merupakan strategi untuk memberikan pelayanan yang berkualitas dan diharapkan menjadi penggerak utama pencapaian tujuan organisasi (Lovelock, 1992). Pelayanan prima berorientasi kepada kepuasan pelanggan. Profesionalisme menjadi kunci strategi pelayanan 
Jurnal Penyuluhan, Maret 2012 Vol. 8 No.1

prima ini dimana sumber daya manusia (SDM) menjadi kunci keberhasilannya. Strategi pelayanan prima berjalan baik jika didukung dengan SDM yang memiliki kompetensi yang relevan dengan bidang-bidang pelayanan yang dikelola. Disinilah permasalahan yang dihadapi oleh pemerintah di daerah. Sejarah panjang dalam pengelolaan birokrasi pemerintah yang sentralistik masih belum dapat sepenuhnya berubah termasuk dalam sistem penerimaan pegawai. Kolusi dan nepotisme masih terus berlangsung dan kompetensi SDM yang sesuai dengan jabatan serta prestasi kerja masih belum mendapatkan prioritas yang sesungguhnya. Penerapan strategi pelayanan prima terkendala oleh minimnya kualitas SDM, tidak hanya dari sisi kemampuan dan kompetensi yang tidak memadai, tetapi juga sikap dan perilaku SDM di lini terdepan layanan (Priyono, 2006; Dwiyanto, 2010, Faozan, 2003).

Upaya peningkatan kualitas pelayanan publik telah banyak dilakukan oleh berbagai pemerintahan daerah, baik kabupaten maupun kota. Tidak cukup hanya dengan memperbaiki struktur kelembagaan, sistem insentif, tetapi juga di dalam penataan proses pelayanan yang diberikan. Pemerintah Kabupaten Sragen dan Sidoarjo telah memanfaatkan alat manajemen yaitu standar ISO 9001 pada BP2T. Sistem manajemen mutu ISO 9001 dikenal dapat memberikan panduan praktek manajemen yang baik dan berorientasi kepada pendekatan PDCA (Plan-Do-Check-Act). Pemanfaatan sistem ini memungkinkan pemerintah daerah mengatur ketentuan-ketentuan pelayanan publik dilaksanakan dengan baik. Penerapan ISO 9001 adalah sebuah perbaikan proses pelayanan publik sehingga diperlukan waktu yang panjang. Berbagai penelitian menyatakan manfaat diterapkannya ISO 9001 yang berdampak positif terhadap kinerja organisasi (Ahmad, 2001; Chu et.al, 2001; Sing dan Nahra, 2006; Hafni, 2004; Sutoyo, 2006, Ollila, 1995). Lebih lanjut dikatakan bahwa penerapan ISO 9001 bermanfaat dari segi efisiensi, yakni terhadap kepuasan pelanggan. Pemerintah Kabupaten Sragen dan Sidoarjo, khususnya unit BP2T diakui telah mampu mengubah paradigma "abdi negara" menjadi "abdi masyarakat". Kesuksesan mereka diakui secara luas dan membawa harapan adanya pelayanan publik yang lebih baik yang bisa menyebar ke daerah-daerah lainnya di seluruh Indonesia. Penelitian ini mengkaji orientasi sikap pegawai terhadap budaya mutu yang muncul sebagai akibat penerapan SMM ISO 9001 dan bagaimana orientasi sikap pegawai tersebut dihubungkan dengan perilaku pegawai dalam memberikan pelayanan kepada masyarakat.

\section{Kajian Teori}

Kajian Harmantyo (2007) menemukan bahwa hingga tahun 2006 dan sebagai akibat dari adanya otonomi daerah, Indonesia telah memiliki lebih kurang 500 kabupaten atau kota dari yang seharusnya berjumlah sekitar 460 buah jika menggunakan perhitungan spasial atau kewilayahan. Pertumbuhan/ pemekaran kota/kabupaten rata-rata 30 daerah otonom setiap tahunnya. Peluang terjadinya konflik kewilayahan dan kesenjangan antar daerah menjadi semakin tinggi. Hal ini belum lagi ditambah dengan berbagai permasalahan birokrasi yang selama ini dikeluhkan. Pola penyelenggaraan pelayanan publik masih memiliki berbagai kelemahan, antara lain: (1) Kurang responsif, (2) Kurang informatif, (3) Kurang accessible (sulit dijangkau), (4) Kurang koordinasi, (5) Terlalu birokratis, (6) Kurang mau mendengarkan keluhan, saran dan aspirasi masyarakat, (7) Inefisien. Berbagai persyaratan yang diperlukan, khususnya dalam pelayanan perijinan, seringkali tidak relevan dengan pelayanan yang diperlukan.

Ketidakberesan pengelolaan pemerintahan yang terjadi tidak hanya di dalam negeri, tetapi juga hampir terjadi di berbagai belahan dunia lainnya sehingga menimbulkan gagasan untuk menata ulang pemerintahan. Osborne dan Gaebler (1992) mengusulkan sepuluh prinsip sederhana dan terstruktur untuk menata ulang pemerintahan yang lebih dikenal dengan "reinventing government". Mereka menyampaikan bagaimana sebuah pemerintahan dikelola dengan cara-cara wirausaha, artinya pemerintahan dikelola dengan cara yang efisien, efektif serta tetap memperhatikan resiko-resiko yang ada. Sebuah pe- 
merintahan yang efisien dan efektif akan bisa terwujud jika pemerintah lebih baik mengarahkan daripada mengayuh, memberikan kewenangan daripada melayani, kompetitif dengan menyuntikkan semangat persaingan ke dalam pemberian pelayanan, digerakkan oleh misi daripada oleh peraturan yang ada, berorientasi kepada hasil dan bukan kepada input, berorientasi kepada pelanggan (masyarakat) bukan kepada birokrasi, mengembangkan prinsip kewirausahaan yakni berprinsip lebih baik menghasilkan daripada membelanjakan, antisipatif, desentralisasi, serta berorientasi kepada pasar yang ada.

Banyaknya kegagalan pemerintah untuk memberikan pelayanan yang bermutu, responsif, dapat dipercaya dan memiliki etika pelayanan yang baik lebih disebabkan karena sumber daya manusia, terutama sikap pegawai pemerintah yang berada di lini terdepan pelayanan. Menurut Koo, Koo dan Tao (1998), sikap pegawai adalah salah satu unsur yang paling rentan di organisasi. Dianggap rentan karena sulit untuk diduga, dan sikap pegawai sangat berpengaruh terhadap upaya perbaikan dan sertifikasi yang diinginkan organisasi. Sikap, menurut Warnaen (2002) adalah kecenderungan seseorang untuk melakukan atau tidak melakukan suatu perilaku tertentu, sehingga sikap bukan hanya kondisi internal psikologis yang murni dari individu (purely psychic inner state), tetapi sikap lebih merupakan proses kesadaran yang sifatnya individual. Artinya proses ini terjadi secara subjektif dan unik pada diri setiap individu. Keunikan ini dapat terjadi oleh adanya perbedaan individual yang berasal dari nilainilai dan norma yang ingin dipertahankan dan dikelola oleh individu. Memahami apa yang dipikirkan pegawai dan mengetahui sikap mereka akan sangat berarti dalam mengembangkan strategi yang tepat untuk mencapai tujuan organisasi.

Sikap timbul karena adanya stimulus atau adanya rangsangan. Terbentuknya sikap dipengaruhi oleh adanya perangsang di lingkungan sosial dan kebudayaannya. Keluarga, norma, adat-istiadat, agama bersama-sama membentuk sikap individu. Sikap individu berkembang sejalan dengan perkembangan biologisnya serta lingkungan dimana ia berada, meskipun sikap tidak selalu berujung kepada perbuatan. Sikap yang berujung kepada perbuatan inilah yang disebut sebagai perilaku. Sikap tidak akan terbentuk tanpa adanya interaksi dengan manusia lain ataupun dengan obyek lainnya.

Ahmadi (2007) menyatakan adanya 2 faktor yang menyebabkan terjadinya perubahan sikap seseorang: (1) faktor internal, dan (2) faktor eksternal. Faktor internal berupa daya pilih seseorang untuk menerima dan mengolah pengaruh dari luar yang biasanya disesuaikan dengan motivasi, sikap dan perhatian yang menjadi minatnya. Sedangkan faktor eksternal berupa interaksi sosial di luar kelompok, antara manusia dengan hasil-hasil kebudayaan, misalnya interaksinya dengan peralatan komunikasi. Sikap dapat diubah atau dibentuk jika terdapat hubungan timbal balik yang langsung antara manusia serta adanya komunikasi langsung dari satu pihak ke pihak lainnya.

ISO 9001 sebagai sebuah alat manajemen telah terbukti mampu memperbaiki kinerja organisasi. Sistem Manajemen Mutu ISO 9001 adalah standar sistem manajemen umum yang dipublikasikan oleh The International Organization for Standardization (ISO), sebuah federasi dari badan-badan standar berbagai negara dengan anggota lebih dari 140 negara. Biasanya standar yang dikeluarkan oleh ISO memiliki spesifikasi teknis, tetapi khusus untuk ISO 9001 ini mendeskripsikan sebuah proses dimana organisasi bisa dan mampu mencapai "mutu produk" yang dijanjikan kepada masyarakat konsumennya. Terdapat delapan unsur yang semestinya dipenuhi, yakni: (1) fokus ke pelanggan, (2) kepemimpinan, (3) keterlibatan setiap orang di dalam organisasi, (4) melalui pendekatan proses, (5) pendekatan sistem terhadap manajemen, (6) perbaikan berkelanjutan, (7) mendasarkan keputusan berdasarkan fakta, serta (8) terciptanya hubungan yang saling menguntungkan dengan pemasok. Berdasarkan kepada delapan prinsip tersebut, Bachmann (2003) melihat bahwa penerapan ISO 9001 sebenarnya adalah membuat sebuah 
Jurnal Penyuluhan, Maret 2012 Vol. 8 No.1

organisasi berbudaya mutu yang berorientasi kepada pelanggannya.

Boomer sebagaimana dikutip Gizzi (2012) menyatakan bahwa budaya mutu dicirikan dengan adanya: (1) sikap, nilai-nilai, praktek-praktek yang mendukung pembelajaran di organisasi, (2) adanya tantangan yang secara terus-menerus dalam melakukan sesuatu untuk selalu memastikan terjadinya efisiensi dan perubahan, (3) adanya dorongan meningkatkan kapasitas pegawai untuk berkontribusi pada proses pengambilan keputusan, baik dalam proses pekerjaan maupun pada tingkat pengambil keputusan, serta (4) bekerja pada berbagai pemangku kepentingan maupun dengan mitra dari luar organisasi. Dalam membangun budaya mutu, selalu ditemui adanya hambatan terkait komitmen, kapasitas, kemampuan memahami pelanggan dan harapannya, pemberdayaan dan pelembagaannya di organisasi. Mutu dianggap sebagai fenomena budaya dimana mutu didekati sebagai sebuah rangkaian nilai, orientasi umum dan ideologi organisasi daripada sebagai serangkaian alat atau teknik organisasi dalam memberikan barang dan jasa kepada pelanggannya (Munhum, et.al, 2010).

Garvin (1988) menyatakan bahwa budaya mutu di organisasi berkembang sepanjang waktu dengan adanya pergeseran nilainilai dan ideologi yang menghargai orang dan berorientasi kepada mutu. Terdapat empat hal yang dapat dilihat dari budaya mutu: (1) budaya pengawasan atau inspection culture, (2) budaya kontrol dengan menggunakan alat statistik (statistical control), (3) budaya penjaminan mutu (quality assurance), dan (4) manajemen strategis terhadap budaya mutu. Sedangkan Cameron dan Sine (1999) melihat ada atau tidaknya budaya mutu di organisasi dengan melihat kepada (1) ketiadaan dorongan mutu (absence of quality emphasis), (2) deteksi terhadap kesalahan (error detections), (3) pencegahan terhadap terjadinya kesalahan (error prevention), dan (4) mutu yang kreatif (creative quality) yang dicirikan oleh adanya antisipasi organisasi terhadap kebutuhan pelanggan dan kecenderungan pelanggan di masa depan. Dari empat penanda tersebut dapat diketahui budaya mutu yang ada dan melembaga di organisasi. Cameron dan Sine lebih lanjut membedakan antara organisasi yang berbudaya mutu tinggi dengan organisasi yang kurang mementingkan budaya mutu sebagaimana Tabel 1 .

Tabel 1 Karakteritik pembeda budaya mutu di organisasi

\begin{tabular}{|c|c|}
\hline $\begin{array}{l}\text { Kurang berbudaya mutu } \\
\text { (less advanced Quality } \\
\text { Culture) }\end{array}$ & $\begin{array}{l}\text { Lebih berbudaya mutu } \\
\text { (more advanced Quality } \\
\text { Culture) }\end{array}$ \\
\hline $\begin{array}{l}\text { - Efektifitas organisasi } \\
\text { rendah } \\
\text { - Kurang menggunakan } \\
\text { peralatan dan teknik } \\
\text { standar mutu, seperti } \\
\text { pemanfaatan ISO } \\
\text { - Kurang menekankan } \\
\text { kepada data, analisa } \\
\text { dan pemanfaatan data } \\
\text { pada pelanggan, } \\
\text { pesaing, pegawai dan } \\
\text { kinerjanya } \\
\text { - Kurang terlihat adanya } \\
\text { pembelajaran } \\
\text { organisasi di } \\
\text { - Kurang terlihat adanya } \\
\text { kordinasi silang dan } \\
\text { secara fungsional } \\
\text { - Kurang memanfaatkan } \\
\text { kerja kelompok/tim } \\
\text { - Kurang memfokuskan } \\
\text { kepada optimalisasi } \\
\text { pemanfaatan SDM } \\
\text { - Mutu bukan merupakan } \\
\text { prioritas tinggi bagi } \\
\text { manajemen }\end{array}$ & 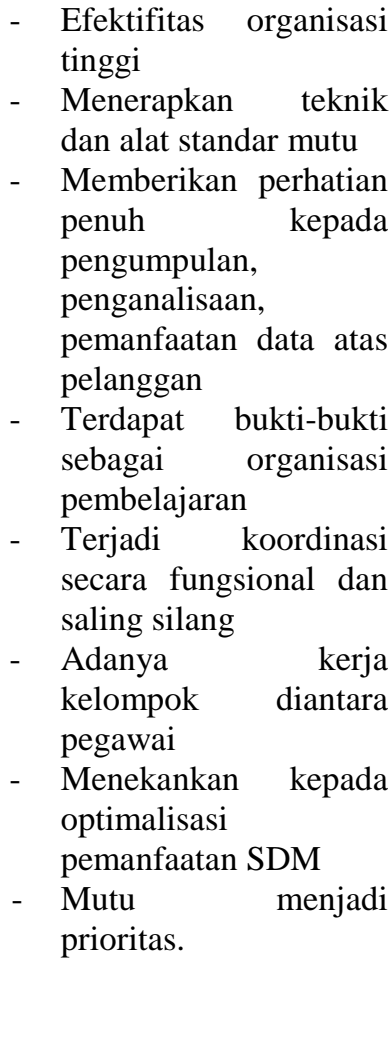 \\
\hline
\end{tabular}

Sumber: Cameron dan Sine, 1999.

\section{Metode Penelitian}

Pemilihan daerah penelitian dilakukan dengan metode purposive sampling dengan pertimbangan sebagai berikut: (1) pemerintah daerah provinsi, kota atau kabupaten yang dipilih adalah mereka yang telah menerapkan sistem pelayanan publik satu pintu atau satu atap; (2) Kantor pelayanan publik satu atap atau satu pintu tersebut telah menerapkan atau pernah menerapkan sistem manajemen mutu ISO 9001 dan telah mendapatkan sertifikat ISO 9001 dari Lembaga Sertifikasi Sistem Mutu. Kantor atau Unit layanan terpadu telah disertifikasi minimal dalam 
kurun waktu tiga tahun; (3) Provinsi, kota atau kabupaten tersebut mendapatkan/ memenangkan Piala Anugerah Citra Pelayanan Prima dari Kementerian Pendayagunaan Aparatur Negara dan Reformasi Birokrasi. Berdasarkan hal tersebut, terdapat 533 pemerintah provinsi, kabupaten dan kota di seluruh Indonesia, dengan rincian sebagai berikut: 33 provinsi, 99 kota, dan 404 kabupaten ${ }^{2}$. Berdasarkan sebaran tersebut, terdapat 397 Badan Pelayanan Perizinan dengan nama yang berbeda-beda. Khusus untuk Badan Pelayanan Perijinan Terpadu (BP2T) juga dikenal dengan nama Badan Pelayanan Perijinan Terpadu dan Penanaman Modal (BPPTPM), atau Kantor Pelayanan Terpadu. Berdasarkan kriteria butir (1) didapatkan 100 Kantor Perijinan Terpadu Satu Pintu (PTSP) yang secara resmi di publikasikan oleh Badan Koordinasi dan Penanaman Modal (BKPM) ${ }^{3}$

Dari 533 Provinsi, Kabupaten dan Kota di seluruh Indonesia, Kantor Pelayanan Terpadu Satu Pintu yang telah menerapkan dan mendapatkan sertifikasi ISO 9001: 2000 dan ISO 9001:2008 sebanyak 46 Kantor dengan rincian: Pemerintah Provinsi sebanyak: 4 buah (Jawa Barat, Jawa Timur, Bali, dan Sulawesi Utara), 22 kota, dan 20 kabupaten. Tahun penerapan dan sertifikasi ISO 9001 sangat beragam, mulai dari tahun 2002 hingga yang baru-baru ini diterima di tahun 2011. Sesuai dengan kriteria butir 2 diambil dua kabupaten terpilih yaitu Kabupaten Sragen, Provinsi Jawa Tengah serta Kabupaten Sidoarjo, Provinsi Jawa Timur. Penelitian dilaksanakan pada bulan September 2011 dan bulan Februari 2012.

Pengumpulan data menggunakan teknik wawancara dan observasi langsung di lapangan. Survei dilakukan dengan pengadministrasian secara berkelompok (Group Administered Survey) yakni di ruang kerja mereka. Dengan cara demikian, pengembalian survey

\footnotetext{
${ }^{2}$ Basis Data Depdagri, diunduh pada 28 Januari 2010 menyebutkan terdapat 399 kabupaten, 98 kota dan 33 provinsi; sedangkan pada data lainnya telah terjadi penambahan kabupaten/kota baru (alamat web kota/kabupaten seluruh Indonesia)

${ }^{3}$ Lihat www.ptsp.bkpm.go.id terkait dengan direktori kantor Pelayanan Terpadu Satu Pintu (PTSP) seluruh Indonesia.
}

(response rate) penelitian ini dapat mendekati 100\%. Validitas dan reliabilitas instrumen penelitian diuji dengan menggunakan uji korelasi Pearson dengan n:36 (responden uji coba), tingkat signifikansi 0.05 diperoleh $\mathrm{r}_{\text {tabel }}$ $=0.361$, diperoleh 137 pertanyaan valid $(>\mathrm{r}$ $=0.361$ ). Data dianalisis dengan menggunakan analisa jalur untuk mengetahui hubungan dan pengaruh variable bebas dengan variable terikat. Analisa deskriptif dilakukan dengan cara membandingkan (comparative) antara dua daerah penelitian untuk mengetahui ada tidaknya perbedaan di antara variable yang diuji pada kedua daerah penelitian.

\section{Hasil Dan Pembahasan}

\section{Badan Pelayanan Perijinan Terpadu (BP2T)}

Respon terhadap terbitnya UndangUndang Otonomi Daerah nomor 32/2004 sangat menggembirakan, tidak saja pada pemekaran daerah-daerah baru untuk merespon kebutuhan masyarakat, tetapi juga munculnya satuan kerja pemerintah daerah (SKPD) yang ditunjuk langsung untuk memberikan pelayanan terdepan ke masyarakat. Salah satu SKPD yang dibentuk sebagai unit percontohan pelaksanaan otonomi daerah di provinsi Jawa Timur adalah BP2T Kabupaten Sidoarjo. BP2T Kabupaten Sragen di Jawa Tengah yang beroperasi secara resmi di tahun 2002 dibentuk melalui Keputusan Nomor :17 Tahun 2002 tanggal 24 Mei 2002 dengan konsep "one stop service", yakni berbagai perijinan yang semula tersebar di berbagai unit kerja diselesaikan di UPT dengan informasi persyaratan yang jelas, target waktu pelayanan yang pasti, dan dengan biaya yang transparan ${ }^{4}$. Sejalan dengan semakin berkembangnya unit pelayanan publik di berbagai pemerintah propinsi, kota dan kabupaten, Menteri Dalam Negeri melalui Peraturan Menteri Nomor: 24 tahun 2006 menegaskan perlunya dibentuk unit pelayanan terpadu satu

\footnotetext{
${ }^{4}$ Surat Ketua DPRD Kabupaten Sragen Nomor 170/288/15/2002 tanggal 27 September 2002 perihal Persetujuan Operasional UPT Kabupaten Sragen.
} 
Jurnal Penyuluhan, Maret 2012 Vol. 8 No.1

pintu (PTSP) non-investasi untuk memberikan pelayanan publik yang lebih baik. Peraturan Pemerintah nomor 41 tahun 2007 melengkapinya dengan Gugus Perangkat Daerah dan organisasi atau tata kerja perangkat daerah (Permendagri Nomor 20/2008).

Tugas dan fungsi Kantor Pelayanan Terpadu memenuhi Peraturan Menteri Negara Pendayagunaan Aparatur Negara Nomor: Per/15/M.PAN/7/2008 tentang Pedoman Umum Reformasi Birokrasi. Adapun salah satu tujuan reformasi birokrasi adalah untuk membentuk profil dan perilaku aparatur yang memiliki integritas tinggi, produktivitas tinggi dan bertanggung jawab, kemampuan memberikan pelayanan yang prima kepada masyarakat melalui birokrasi yang bersih, efisien, efektif, produktif, transparan, dan akuntabel. Kualitas pelayanan aparatur pemerintah kepada masyarakat menjadi indikator keberhasilan otonomi daerah. BP2T Kabupaten Sragen melayani 59 jenis perijinan dan 10 jenis non perijinan (KTP, KK, Capil) dan didukung oleh 43 pegawai, PNS maupun pegawai tidak tetap (PTT), sedangkan BP2T Kabupaten Sidoarjo melayani 25 jenis perijinan dan didukung oleh 69 pegawai, baik PNS maupun PTT.

\section{Orientasi Sikap Pegawai}

Terdapat delapan unsur yang semestinya dipenuhi pada penerapan SMM ISO 9001, yakni: (1) fokus ke pelanggan, (2) kepemimpinan, (3) keterlibatan setiap orang di dalam organisasi, (4) melalui pendekatan proses, (5) pendekatan sistem terhadap manajemen, (6) perbaikan berkelanjutan, (7) mendasarkan keputusan berdasarkan fakta, serta (8) terciptanya hubungan yang saling menguntungkan dengan pemasok.Sikap pegawai yang dikaji dalam penelitian ini direfleksikan

Tabel 2 Sikap pegawai terhadap penerapan SMM ISO 9001

\begin{tabular}{|c|c|c|c|c|c|c|c|c|}
\hline \multirow[t]{2}{*}{ Variabel yang diukur } & \multicolumn{2}{|c|}{ Kategori } & \multicolumn{2}{|c|}{ Sragen } & \multicolumn{2}{|c|}{ Sidoarjo } & \multicolumn{2}{|c|}{ Total } \\
\hline & & & $\mathrm{N}$ & $\%$ & $\mathrm{~N}$ & $\%$ & $\mathrm{n}$ & $\%$ \\
\hline \multirow[t]{6}{*}{ Sikap } & Rendah & $30,00-52,99$ & 0 & 0,00 & 0 & 0,00 & 0 & 0,00 \\
\hline & Sedang & $53,00-74,99$ & 0 & 0,00 & 1 & 1,89 & 1 & 1,04 \\
\hline & Tinggi & $75,00-96,99$ & 27 & 62,79 & 46 & 86,79 & 73 & 76,04 \\
\hline & Sangat tinggi & $97,00-120,00$ & 16 & 37,21 & 6 & 11,32 & 22 & 22,92 \\
\hline & & Rataan skor & & 94,05 & & 89,26 & & 91,41 \\
\hline & & Kategori & & tinggi & & tinggi & & tinggi \\
\hline \multirow[t]{6}{*}{ Terhadap Mutu } & Rendah & $8,00-13,99$ & 0 & 0 & 0 & 0 & 0 & 0 \\
\hline & Sedang & $14,00-19,99$ & 0 & 0 & 1 & 1,89 & 1 & 1,04 \\
\hline & Tinggi & $20,00-25,99$ & 12 & 27,91 & 26 & 49,06 & 38 & 39,58 \\
\hline & Sangat tinggi & $26,00-32,00$ & 31 & 72,09 & 26 & 49,06 & 57 & 59,38 \\
\hline & & Rataan skor & & 25,49 & & 27,65 & & 26,46 \\
\hline & & Kategori & & tinggi & San & tinggi & San & t tinggi \\
\hline \multirow{6}{*}{$\begin{array}{l}\text { Terhadap } \\
\text { Keterlibatan di organisasi }\end{array}$} & Rendah & $8,00-13,99$ & 0 & 0,00 & 0 & 0,00 & 0 & 0,00 \\
\hline & Sedang & $14,00-19,99$ & 6 & 13,95 & 4 & 7,55 & 10 & 10,42 \\
\hline & Tinggi & $20,00-25,99$ & 13 & 30,23 & 36 & 67,92 & 49 & 51,04 \\
\hline & Sangat tinggi & $26,00-32,00$ & 24 & 55,81 & 13 & 24,53 & 37 & 38,54 \\
\hline & & Rataan Skor & & 24.93 & & 24,11 & & 24,48 \\
\hline & & Kategori & & tinggi & & tinggi & & Tinggi \\
\hline \multirow{6}{*}{$\begin{array}{l}\text { Terhadap pengembangan } \\
\text { diri }\end{array}$} & Rendah & $7,00-12,99$ & 0 & 0,00 & 5 & 9,43 & 5 & 5,21 \\
\hline & Sedang & $13,00-17,99$ & 10 & 23,26 & 16 & 30,19 & 26 & 27,08 \\
\hline & Tinggi & $18,00-22,99$ & 30 & 69,77 & 29 & 54,72 & 59 & 61,46 \\
\hline & Sangat tinggi & $23,00-28,00$ & 3 & 6,97 & 3 & 5,66 & 6 & 6,25 \\
\hline & & Rataan Skor & & 18,86 & & 17,32 & & 18,01 \\
\hline & & Kategori & & tinggi & & sedang & & Tinggi \\
\hline \multirow{6}{*}{$\begin{array}{l}\text { Internalisasi nilai } \\
\text { kepemimpinan }\end{array}$} & Rendah & $7,00-12,99$ & 0 & 0 & 0 & 0 & 0 & 0 \\
\hline & Sedang & $13,00-17,99$ & 0 & 0 & 1 & 1,89 & 1 & 1,04 \\
\hline & Tinggi & $18,00-22,99$ & 28 & 65,12 & 30 & 56,60 & 58 & 60,41 \\
\hline & Sangat tinggi & $23,00-28,00$ & 15 & 34,88 & 22 & 41,51 & 37 & 38,54 \\
\hline & & Rataan Skor & & 22,60 & & 22,34 & & 22,46 \\
\hline & & Kategori & & tinggi & & tinggi & & Tinggi \\
\hline
\end{tabular}

Sumber data: Pengolahan data lapangan, 2011

Keterangan $: \mathrm{n}$ Sragen $=43 ; \mathrm{n}$ Sidoarjo $=53 ; \mathrm{n}$ total $=96$ 
Jurnal Penyuluhan, Maret 2012 Vol. 8 No.1

oleh indikator: (1) pandangan atau orientasi pegawai terhadap mutu, (2) keterlibatan pegawai secara aktif di organisasi, (3) terhadap kesadaran untuk pengembangan diri serta (4) terhadap kemampuan pegawai menginternalisasikan fungsi kepemimpinan di dalam dirinya.

Sebagaimana disebutkan pada konseptualisasi dan definisi operasional penelitian, sikap dimaksudkan sebagai konsistensi pegawai dalam merespon manajemen mutu, partisipasi atau keterlibatan aktif pegawai didalam tim, kelompok, organisasi, sikap pegawai terhadap kebutuhan untuk mengembangkan diri, serta sikap pegawai dalam menginternalisasikan sifat-sifat kepemimpinan kedalam diri pribadi sebagai individu. Sikap dimaksudkan adalah sikap positif atau negatif terhadap penerapan SMM ISO 9001.

Sikap pegawai di BP2T Kabupaten Sragen dan BP2T Kabupaten Sidoarjo terkait mutu pelayanan disajikan pada Tabel 2 .

Dari Tabel 2 tersebut diatas terlihat bahwa seluruh pegawai memiliki sikap yang sangat positif terhadap diterapkannya SMM ISO 9001 dimana jawaban responden termasuk kedalam kategori tinggi dan sangat $(98,96 \%)$. Artinya, tidak ada keraguan sama sekali untuk mendukung penerapan SMM ISO 9001 di organisasinya. Tidak ada perbedaan sikap baik di BP2T Sragen maupun di BP2T Sidoarjo. Sikap pegawai dalam mendukung penerapan SMM ISO 9001 ini dapat dilihat dari beberapa sub variabel yang mendukung, diantaranya: sikap pegawai khususnya terhadap mutu, sikap pegawai terkait dengan pelaksanaan prinsip keterlibatan setiap orang di organisasi atau partisipasi aktif setiap orang diorganisasi (involvement of people), sikap pegawai terhadap prinsip "continual improvement" atau peningkatan berkelanjutan organisasi dan pengembangan diri individu, serta sikap pegawai terhadap berkembangnya nilainilai atau sifat-sifat kepemimpinan di setiap lini di organisasi, khususnya pada level individu pegawai.

\section{Sikap Pegawai terhadap Mutu}

Penerapan SMM ISO 9001 membutuhkan sebuah organisasi yang memiliki budaya tersendiri, demikian pula individu-individu di dalamnya. Individu yang memiliki orientasi sikap terhadap mutu, baik mutu kinerja organisasi maupun mutu kinerja individu akan lebih mudah menerima dan menjalankan SMM ISO 9001 di organisasinya (Koo, Koo dan Tao, 1998). Sikap pegawai terhadap penerapan SMM ISO 9001 sangat tinggi, yang direpresentasikan oleh sebagian besar atau 57 orang $(59,38 \%)$. Pegawai menyatakan pemahaman mereka yang semakin baik terhadap apa yang dimaksudkan sebagai organisasi yang bermutu, memastikan bahwa organisasi memiliki sasaran mutu, dimana penerapan dan sertifikasi yang diterima organisasi telah mendorong semangat mereka untuk bekerja lebih baik lagi untuk masyarakat. Pegawai juga menyatakan tingginya minat untuk mempelajari SMM ISO 9001. Menurut responden, dengan adanya sistem, mekanisme dan prosedur yang ada telah membantu mereka melaksanakan tugas, membuat mereka bekerja lebih efisien tanpa harus setiap kali menunggu arahan pimpinan karena kejelasan tugas-tugas, batasan kewenangan yang mereka miliki. Sistem dan prosedur yang dibuat dipahami tidak hanya sebagai sebuah pemenuhan terhadap Undang-undang atau peraturan lain yang mengikat tetapi telah bisa membantu responden mempermudah pelaksanaan tugas. Mereka yakin bahwa penerapan SMM ISO 9001 ini telah meningkatkan kepuasan masyarakat dan tidak hanya menguntungkan segelintir orang di organisasi atau di masyarakat.

\section{Sikap keterlibatan aktif (involvement of people) di organisasi}

Menunjukkan seberapa banyak keterlibatan pegawai dalam berbagai kegiatan organisasi dan sosial yang berujung kepada keberdayaannya di dalam kelompok dan organisasi. Parameter yang dipergunakan untuk mengukur keterlibatan aktif terdiri dari frekwensi keikutsertaan pegawai dalam kegiatan kelompok, dalam kegiatan organisasi 
Jurnal Penyuluhan, Maret 2012 Vol. 8 No.1

serta berperan langsung di dalam struktur organisasi tersebut.

Keterlibatan aktif setiap orang di organisasi adalah prinsip ketiga dari SMM ISO 9001, yakni terjadi perubahan paradigma dari yang hanya beroperasi sesuai dengan ketentuan menjadi bekerja sama dengan lebih baik. Keterlibatan aktif setiap orang diantaranya adalah partisipasi dalam membuat disain, terlibat dalam menetapkan tujuan, menetapkan kewenangan dan tanggung jawab, menciptakan lingkungan yang kondusif dimana mereka bisa bekerja secara optimal, berpartisipasi dalam komunikasi internal serta mampu mengidentifikasi kompetensi yang diperlukan. Dari Tabel 2 menunjukkan bahwa keterlibatan responden dalam berbagai kegiatan organisasi termasuk kedalam kategori tinggi dan merata di dua daerah penelitian. Sebanyak 51,04\% atau 49 orang responden menyatakan memiliki tingkat partisipasi yang tinggi dan 37 orang atau 38,54\% terlibat secara langsung dalam proses manajemen mutu organisasi dengan tingkat keterlibatan yang sangat tinggi. Hanya 10 responden $10,42 \%$ ). Responden menganggap bahwa keterlibatan mereka secara langsung merupakan bagian yang tidak terpisahkan dari pengembangan organisasi. Hanya 10,42\% responden yang termasuk kedalam kategori sedang-sedang saja. Artinya, kebebasan yang diberikan organisasi untuk dapat berpartisipasi mengemukakan pendapat, saran, keluhan belum dimanfaatkan secara optimal.

\section{Pengembangan diri}

Pengembangan diri diterjemahkan dari prinsip SMM ISO 9001 yakni "peningkatan berkelanjutan atau continual improvement" (Hoyle, 2009). Manajemen organisasi harus selalu berorientasi kepada kepuasan pelanggan, oleh sebab itu, diperlukan berbagai upaya untuk selalu dapat memenuhi kepuasan pelanggan. Bagi organisasi sebagaimana Pemerintah Daerah, pelanggan adalah masyarakat. Peningkatan mutu layanan menjadi tanggung jawab setiap orang di organisasi, bukan hanya tanggung jawab manajer mutu atau wakil manajemen atau pimpinan organisasi. Inti dari peningkatan berkelanjutan adalah kinerja, metode dan target yang semakin baik dan meningkat. Ketiga hal tersebut hanya dapat dicapai jika setiap orang selalu mencari jalan dan metode terbaik untuk menyelesaikan target dan memuaskan pelanggannya. Konsep ini yang mensyaratkan organisasi untuk memiliki program untuk menjaga dan meningkatkan kompetensi pegawainya.

Pada penelitian ini parameter yang digunakan untuk mengukur tingkat kedewasaan atau kesadaran pengembangan diri responden adalah banyaknya waktu dan sumberdaya lain yang dicurahkan pegawai untuk melakukan kegiatan pengembangan diri, kompetensi, kapasitas dan karirnya di organisasi. Parameter yang digunakan dalam penelitian ini adalah: waktu yang cukup untuk mencari kesempatan mengikuti diklat, menyediakan anggaran yang cukup sesuai kebutuhan, tidak menggantungkan diri kepada ketersediaan anggaran organisasi, serta menyediakan waktu yang cukup untuk belajar secara otodidak.

Sebaran sikap responden terhadap keinginan mengembangkan diri disajikan pada Tabel 2 menyatakan bahwa sikap responden terkait dengan upaya pengembangan diri termasuk dalam kategori tinggi, hanya saja tidak merata di dua daerah penelitian. Responden di Kabupaten Sragen memiliki sikap positif terhadap pengembangan diri dalam kategori tinggi, sedangkan responden di Kabupaten Siidoarjo sikap positif mereka terhadap pengembangan diri hanya masuk dalam kategori sedang. Secara keseluruhan terdapat 59 orang yang memiliki sikap positif yang tinggi terhadap pengembangan diri, 26 orang menganggap sedang-sedang saja dan 6 orang menganggap kesempatan mengembangkan diri sebagai sebuah kesempatan yang sangat baik dan sangat positif. Sebanyak $67,71 \%$ responden menganggap pengembangan diri sangat tinggi dan tinggi yang membuat mereka memiliki kesempatan untuk mendapatkan tugas dan peran yang menantang.

\section{Internalisasi nilai kepemimpinan}

Esensi dari sifat kepemimpinan adalah mengajak, mempersuasi orang-orang untuk dapat bekerja bersama-sama mencapai suatu 
tujuan organisasi. Kepemimpinan sebagai penggerak, dinamisator dan koordinator sumber daya yang dimiliki organisasi. Seorang pemimpin dituntut untuk memiliki beberapa kapasitas dan kemampuan, diantaranya: kemampuan berbicara, menilai, mendengarkan, berempati, mandiri, memberikan solusi dan membantu memahami persoalan, serta memiliki kemampuan melayani, terbuka dan mudah bergaul (Kartono, 2006).

Dari sedemikian banyak sifat-sifat peimpin yang diharapkan, penelitian ini menggunakan parameter sifat kepemimpinan yang dikembangkan oleh Geoge R. Terry tentang trait leadership. Parameter yang diambil meliputi kemampuan responden memahami esensi kepemimpinan dalam menggerakkan orang lain, kemampuan dan kecakapan teknisnya menjadikannya tempat untuk bertanya, memiliki stabilitas emosi yang cukup baik terkait dengan hubungan antar teman, kemandirian, dan sebagainya. Tabel 2 menyajikan jawaban responden terkait dengan upaya-upaya internalisasi sifat kepemimpinan. Hasil penelitian lapangan menunjukkan bahwa internalisasi sifat kepemimpinan di dalam individu di organisasi termasuk kedalam kategori tinggi. Angka tersebut merata di dua daerah penelitian. Dapat disimpulkan bahwa sebagian besar responden baik di Sragen maupun Sidoarjo telah mampu melakukan internalisasi sifat-sifat kepemimpinan dalam melaksanakan tugas-tugas yang dibebankan kepadanya, dimana mereka yang termasuk dalam kategori tinggi berjumlah 58 orang atau $60,41 \%$ dan mereka yang termasuk dalam kataegori sangat tinggi sebesar 37 orang atau $38,54 \%$. Dapat disimpulkan pegawai di dua daerah penelitian memiliki sifat dan sikap kemandirian yang tinggi, mampu memotivasi lingkungan kerja, menjadikan diri sebagai tempat untuk bertanya karena kemampuan teknis yang dimilikinya dan kemampuan tersebut merata di seluruh individu. Responden sepakat untuk saling berbagi ilmu dan informasi, dan berbagi cara untuk menyelesaikan permasalahan secara bersama sebelum akhirnya harus diputuskan oleh pimpinan.

Hasil penelitian menyatakan bahwa sikap pegawai berpengaruh positif dan nyata terhadap perilaku pegawai pada pelayanan publik. Semakin positif sikap pegawai terhadap mutu dan nilai-nilai SMM ISO 9001 akan semakin terefleksikan pada positifnya perilaku pegawai yang responsif, akuntabel dan beretika dalam pemberian pelayanan. Temuan ini sejalan dengan hasil penelitian Warner dan De Fleur (Ahmadi, 2007) tentang adanya hubungan langsung antara sikap dan tingkah laku. Pada kasus ini, terjadi konsistensi hubungan sikap dan perilaku yang dipengaruhi oleh lingkungan terdekat dalam kehidupan sehari-hari, yakni organisasi. Sebagai sebuah kecenderungan positif atau negatif yang berhubungan dengan obyek psikologis tertentu, sikap positif pegawai ditunjukkan dalam bentuk perilaku yang positif terhadap penerapan SMM ISO 9001. Terkait dengan peran sikap individu yang berhubungan secara konsisten dengan perilakunya, hal ini sejalan dengan formulasi Bandura yang menyatakan bahwa perilaku merupakan fungsi dari individu (person) dan lingkungan dimana ia berada. Kantor BP2T yang telah menerapkan SMM ISO 9001 selama bertahun-tahun secara langsung mempengaruhi cara kerja pegawai. Pegawai dipandu melaksanakan pekerjaan dengan panduan mutu, instruksi kerja yang jelas, terarah, dan lebih pasti atas kinerja yang harus dihasilkan. Pembelajaran sosial di organisasi telah membentuk budaya organisasi yang berorientasi kepada pentingnya pelayanan kepada masyarakat. Meningkatnya sikap positif pegawai terhadap mutu dan SMM ISO 9001 tidak terjadi secara tiba-tiba, tetapi ia melalui serangkaian proses dan waktu yang panjang (lebih dari delapan tahun) yang berujung kepada positifnya perilaku pegawai terhadap SMM ISO 9001 dan pelayanan masyarakat. Pembentukan perilaku yang demikian ini sejalan dengan teori Skinner tentang pembentukan perilaku melalui pembiasaan (conditioning) atau perilaku yang dibentuk karena sebuah proses belajar yang dilalui individu (operant conditioning). Perilaku yang dibentuk melalui proses belajar ini menurut Skinner akan menjadi perilaku yang lebih dominan pada individu. Pegawai di kedua daerah penelitian bekerja melayani 
Jurnal Penyuluhan, Maret 2012 Vol. 8 No.1

masyarakat dibawah sebuah sistem manajemen bertaraf internasional dan diakui telah mampu meningkatkan kinerja pemerintah daerah mata masyarakat (Dwiyanto, 2010). Sikap positif pegawai terhadap penerapan SMM 9001 ini juga sejalan dengan Nasution (2005) tentang pengaruh implementasi SMM terhadap partisipasi dan komitmen pegawai terhadap mutu, tumbuhnya rasa bangga bekerja sehingga akan bekerja secara optimal serta tumbuhnya rasa tanggung jawab untuk meningkatkan kinerja organisasi.

Terkait dengan perilaku pegawai terhadap pelayanan masyarakat yang responsif, dapat diandalkan dan memiliki etika pelayanan yang baik, pegawai di dua daerah penelitian memiliki perilaku yang sangat responsif, dapat diandalkan dan memiliki etika yang dibuktikan dengan perilaku mereka yang termasuk pada kategori sangat tinggi.

\section{Perilaku Responsif}

Responsif menurut KBBI diartikan sebagai cepat merespon, bersifat menanggapi, tergugah hati, bersifat memberi tanggapan atau tidak masa bodoh. Perilaku responsif dapat didefinisikan sebagai reaksi, gerakan lahiriah atau fisik, pernyataan-pernyataan verbal dan pengalaman subyektif pegawai dalam memberikan pelayanan publik kepada masyarakat secara cepat dan penuh perhatian. Tanggapan responden atas perilaku responsif dalam melayani masyarakat disajikan pada Tabel 3.

Pegawai BP2T sebagai responden penelitian ini memiliki perilaku yang sangat responsif terhadap kegiatan pelayanan perijinan dan non-perijinan yang diberikan kepada masyarakat. $98 \%$ lebih responden berada ppada kategori perilaku responsif yang tinggi dan sangat tinggi atau sangat responsif. Hanya sebagian kecil saja $(2,08 \%)$ yang berada pada kategori sedang. Tidak ada perbedaan yang cukup signifikan dari ke dua daerah penelitian.

\section{Perilaku yang dapat diandalkan (reliable)}

Sebuah perilaku yang dapat diandalkan (reliable) adalah sebuah tindakan, pernyataan verbal responden yang dapat memberi jaminan bahwa jasa pelayanan publik yang diinginkan oleh masyarakat dapat diterima sesuai dengan janji yang telah diikrarkan pada piagam pelayanan yang ada. Perilaku responden dalam memberi pelayanan dapat dilihat secara fisik ketika mereka melayani dengan keterampilan psikomotoriknya, yakni mengoperasikan berbagai peralatan pendukung yang digunakan dalam memberikan jasa.

Beberapa parameter yang digunakan untuk melihat reliabilitas pemberi layanan (service provider) kepada penerima layanan (masyarakat), diantaranya adalah kemauan responden dalam memberikan pelayanan sesuai prosedur yang berlaku, jujur dalam memberikan keterangan, tidak berbelit-belit, memperhatikan proses pelayanan termasuk waktu pelayanan yang dipergunakan, memberikan perhatian yang sama (adil) kepada seluruh masyarakat yang memerlukan. Responden diharapkan memiliki pengetahuan dan keterampilan mengoperasikan peralatan yang digunakan (dokumen, alat tulis, dan peralatan penunjang lainnya) dengan meyakinkan dengan kesalahan yang sangat minimal. Terpenuhinya parameter tersebut akan membuat

Tabel 3 Sebaran responden atas perilaku responsif

\begin{tabular}{|c|c|c|c|c|c|c|c|}
\hline \multicolumn{2}{|c|}{ Kategori } & \multicolumn{2}{|c|}{ Sragen } & \multicolumn{2}{|c|}{ Sidoarjo } & \multicolumn{2}{|c|}{ Total } \\
\hline & & $\mathrm{N}$ & $\%$ & $\mathrm{n}$ & $\%$ & $\mathrm{n}$ & $\%$ \\
\hline Rendah & $5,00-8,75$ & 0 & 0,00 & 0 & 0,00 & 0 & 0,00 \\
\hline Sedang & $8,76-12,51$ & 1 & 2,32 & 1 & 1,89 & 2 & 2,08 \\
\hline Tinggi & $12,52-16,27$ & 26 & 60,47 & 36 & 67,92 & 62 & 64,58 \\
\hline Sangat tinggi & $16,28-20,03$ & 16 & 37,21 & 16 & 30,19 & 32 & 33,34 \\
\hline & jumlah & 43 & 100,00 & 53 & 100,00 & 96 & 100,00 \\
\hline & Rataan skor & & 16,40 & & 16,06 & & 16,21 \\
\hline & Kategori & & at tinggi & & at tinggi & & at tinggi \\
\hline
\end{tabular}

Sumber: Pengolahan data lapangan, 2011 
Jurnal Penyuluhan, Maret 2012 Vol. 8 No.1

Tabel 4 Sebaran responden terkait perilaku handal (reliable)

\begin{tabular}{|c|c|c|c|c|c|c|c|}
\hline \multicolumn{2}{|c|}{ Kategori } & \multicolumn{2}{|c|}{ Sragen } & \multicolumn{2}{|c|}{ Sidoarjo } & \multicolumn{2}{|c|}{ Total } \\
\hline & & $\mathrm{n}$ & $\%$ & $\mathrm{n}$ & $\%$ & $\mathrm{n}$ & $\%$ \\
\hline Rendah & $6,00-9,99$ & 0 & 0,00 & 0 & 0,00 & 0 & 0,00 \\
\hline Sedang & $10,00-14,99$ & 0 & 0,00 & 1 & 1,89 & 1 & 1,04 \\
\hline Tinggi & $15,00-18,99$ & 4 & 9,31 & 8 & 15,09 & 12 & 12,50 \\
\hline \multirow[t]{2}{*}{ Sangat tinggi } & $19,00-24,00$ & 39 & 90,69 & 44 & 83,02 & 83 & 86,46 \\
\hline & jumlah & 43 & 100,00 & 53 & 100,00 & 96 & 100,00 \\
\hline \multicolumn{2}{|c|}{ Rataan skor } & \multicolumn{2}{|c|}{16,40} & \multicolumn{2}{|c|}{16,06} & \multicolumn{2}{|c|}{16,21} \\
\hline \multicolumn{2}{|c|}{ Kategori } & \multicolumn{2}{|c|}{ Sangat tinggi } & \multicolumn{2}{|c|}{ Sangat tinggi } & \multicolumn{2}{|c|}{ Sangat tinggi } \\
\hline
\end{tabular}

Sumber: Pengolahan data lapangan, 2011

penerima layanan mendapatkan keyakinan (assurance) bahwa dia akan mendapatkan pelayanan sesuai dengan harapannya (Riduwan,2009). Tabel 4 menyajikan sebaran perilaku responden yang dapat diandalkan dalam memberikan pelayanan kepada masyarakat.

Temuan di lapangan mengindikasikan bahwa perilaku responden yang dapat diandalkan masyarakat sudah demikian merata di dua tempat penelitian, Sragen dan Sidoarjo. Ini terbukti dari 82 orang atau $86,46 \%$ responden sepakat bahwa mereka telah mampu merespon tuntutan penerima layanan untuk berperilaku yang dapat menimbulkan rasa kenyamanan dan kepercayaan masyarakat, yakni termasuk pada kategori yang sangat tinggi. Sebanyak 12 orang menyatakan mereka memiliki keyakinan mampu memberikan pelayanan yang memuaskan masyarakat dalam kategori yang tinggi dan hanya 1 orang atau $1.04 \%$ yang masuk kedalam kategori sedang. Observasi yang dilakukan dilapangan juga telah memberi keyakinan bahwa para petugas yang ditempatkan dibagian depan (front line staff, customer service), yang berhubungan langsung dengan masyarakat benar-benar menguasai bidang tugasnya, cepat merespon dan memberikan penjelasan yang demikian rinci tanpa melihat ulang persyaratan, dokumen dan mekanisme yang seharusnya ditempuh penerima layanan. Menurut pimpinan BP2T, petugas front line diharuskan mampu memahami dan menyampaikan keseluruhan persyaratan perijinan yang berlaku kepada masyarakat yang datang ke kantor BP2T.

\section{Etika Pelayanan}

Etika menurut Kamus Besar Bahas Indonesia (KBBI) adalah apa yang dianggap baik dan buruk tentang hak dan kewajiban moral. Integritas dan etika dalam pelayanan publik berkaitan dengan komitmen kejujuran untuk melaksanakan segala tugas dan tanggung jawab sesuai dengan ketentuan yang berlaku. Etika adalah nilai-nilai keadilan, persamaan, kebebasan sebagai dasar pengambilan keputusan terhadap berbagai alternatif kebijakan dalam melaksanakan tugas. Etika pelayanan tidak cukup hanya berdasarkan kepada nilai ekonomis dan efisiensi, tetapi perlu memasukkan nilai-nilai kesetaraan sosial (social equity) bagi masyarakat maupun individu. Standar etika, oleh karenanya bukan sesuatu yang statis tetapi berkembang dari waktu ke waktu sesuai

Tabel 5 Tanggapan responden tentang perilaku beretika pelayanan

\begin{tabular}{|c|c|c|c|c|c|c|c|}
\hline \multicolumn{2}{|c|}{ Kategori } & \multicolumn{2}{|c|}{ Sragen } & \multicolumn{2}{|c|}{ Sidoarjo } & \multicolumn{2}{|c|}{ Total } \\
\hline & & $\mathrm{n}$ & $\%$ & $\mathrm{n}$ & $\%$ & $\mathrm{n}$ & $\%$ \\
\hline Rendah & $6,00-9,99$ & 0 & 0,00 & 0 & 0,00 & 0 & 0,00 \\
\hline Sedang & $10,00-14,99$ & 0 & 0,00 & 3 & 5,66 & 3 & 3,12 \\
\hline Tinggi & $15,00-18,99$ & 9 & 20,93 & 24 & 45,28 & 33 & 34,38 \\
\hline \multirow[t]{4}{*}{ Sangat tinggi } & $19,00-24,00$ & 34 & 79,07 & 26 & 49,06 & 60 & 62,50 \\
\hline & jumlah & 43 & 100,00 & 53 & 100,00 & 96 & 100,00 \\
\hline & Rataan skor & \multicolumn{2}{|c|}{20.30} & \multicolumn{2}{|c|}{19,21} & \multicolumn{2}{|c|}{19,70} \\
\hline & Kategori & \multicolumn{2}{|c|}{ Sangat tinggi } & \multicolumn{2}{|c|}{ Sangat tinggi } & \multicolumn{2}{|c|}{ Sangat tinggi } \\
\hline
\end{tabular}

Sumber: Pengolahan data lapangan, 2011 
Jurnal Penyuluhan, Maret 2012 Vol. 8 No.1

standar perilaku yang merefleksikan nilai-nilai dasar masyarakat yang dilayani. Sopan santun, ramah tamah, melayani dengan baik, bertindak adil kepada setiap pengguna layanan adalah harapan masyarakat terhadap pelayanan publik yang semestinya ditawarkan oleh Pemerintah Daerah. Tabel 5 menyajikan sebaran etika pelayanan yang dipahami dan dilakukan responden dalam melayani masyarakat.

Etika pelayanan yang dimiliki responden berada pada kategori yang tinggi $(34,38 \%)$ dan sangat tinggi $(62,50 \%)$. Artinya responden memiliki kesadaran untuk memberikan pelayanan kepada masyarakat dengan perilaku yang tanggap terhadap kebutuhan masyarakat, sopan, ramah, bersahabat, jujur, melayani dengan sepenuh hati, bertindak adil, serta berusaha membuat masyarakat penerima layanan merasa dihormati dan nyaman ketika mencari pelayanan jasa yang mereka butuhkan. Sebanyak 93 orang menyatakan telah memiliki etika pelayanan sebagaimana yang diharapkan masyarakat. Sementara 3,12\% sisanya atau 3 orang responden termasuk kedalam kategori beretika sedang. Tidak ada satupun pegawai yang memiliki etika pelayanan yang rendah. Responden berperilaku sebagaimana yang diharapkan ketika berhadapan atau melayani masyarakat yang datang. Kenyataan di lapangan menunjukkan bahwa responden yang menyatakan tidak pernah berperilaku sebagaimana diharapkan masyarakat karena memang tidak memiliki tugas yang berhubungan langsung dengan masyarakat, sehingga tidak ada kesempatan untuk memberikan pelayanan.

Temuan di lapangan memberikan pemahaman bahwa perubahan perilaku pegawai dalam memberikan pelayanan kepada masyarakat dapat terjadi karena adanya dorongan sikap positif pegawai terhadap penerapan SMM ISO 9001, adanya motivasi intrinsik pegawai yang tinggi, serta adanya metode pembelajaran di organisasi yang sesuai dengan kebutuhan pegawai untuk mengembangkan pengalaman, kapasitas dan kompetensinya menjalankan tugas. Stimulus variabel terjadinya perubahan perilaku tersebut sejalan dengan temuan Rustandi (2010) tentang stimulus yang diperlukan santri untuk berubah ke perilaku santri yang memiliki kompetensi di agribisnis. Motivasi, belajar, sikap dan nilai yang ditanamkan oleh para ustadz untuk memiliki etos kerja yang tinggi, bukan kepada hasil yang tinggi merupakan stimulus variabel yang berpengaruh terhadap terjadinya perilaku agribisnis santri. Sikap pegawai yang berperan besar dalam perilaku pelayanan publik juga sejalan dengan temuan Koo, Koo dan Tao (1998) dimana mengetahui lebih dalam tentang sikap pegawai dan apa yang mereka pikirkan berpengaruh besar terhadap sertifikasi ISO. Jika persepsi pegawai benar terhadap ISO, maka akan memberi mereka cukup banyak ruang untuk meningkatkan kontribusinya ke organisasi. Menurut mereka, pegawai adalah satu-satunya aset yang sangat rentan untuk diduga. Temuan Koo, Koo dan Tao juga menyatakan bahwa sikap merupakan faktor yang berdiri sendiri dalam memberikan pengaruh pada pencapaian sertifikasi ISO di organisasi.

\section{Pengaruh Sikap Pegawai terhadap Perilaku Pelayanan Publik}

Hasil analisis jalur menunjukkan bahwa secara parsial sikap pegawai terhadap mutu (0.269), keterlibatan aktif pegawai (0.269), pengembangan diri (0.368), dan internalisasi sifat-sifat kepemimpinan (0.292) memberikan pengaruh positif dan nyata kepada perilaku pegawai pada pelayanan publik. Sikap pegawai secara bersama-sama memberikan pengaruh positif dan nyata terhadap perilaku pegawai pada pelayanan publik (0.367). Gambar 1 menunjukkan hubungan antara sikap pegawai terhadap mutu dengan perilaku pegawai pada pelayanan publik. Sikap pegawai terhadap mutu yang direpresentasikan oleh empat sub peubah: terhadap mutu, terhadap keterlibatan aktif di organisasi dan lingkungan sosial, terhadap pengembangan diri, dan terhadap bagaimana pegawai menyikapi sifat-sifat kepemimpinan diinternalisasikan kepada diri sendiri memberi pengaruh positif terhadap perilaku pegawai 


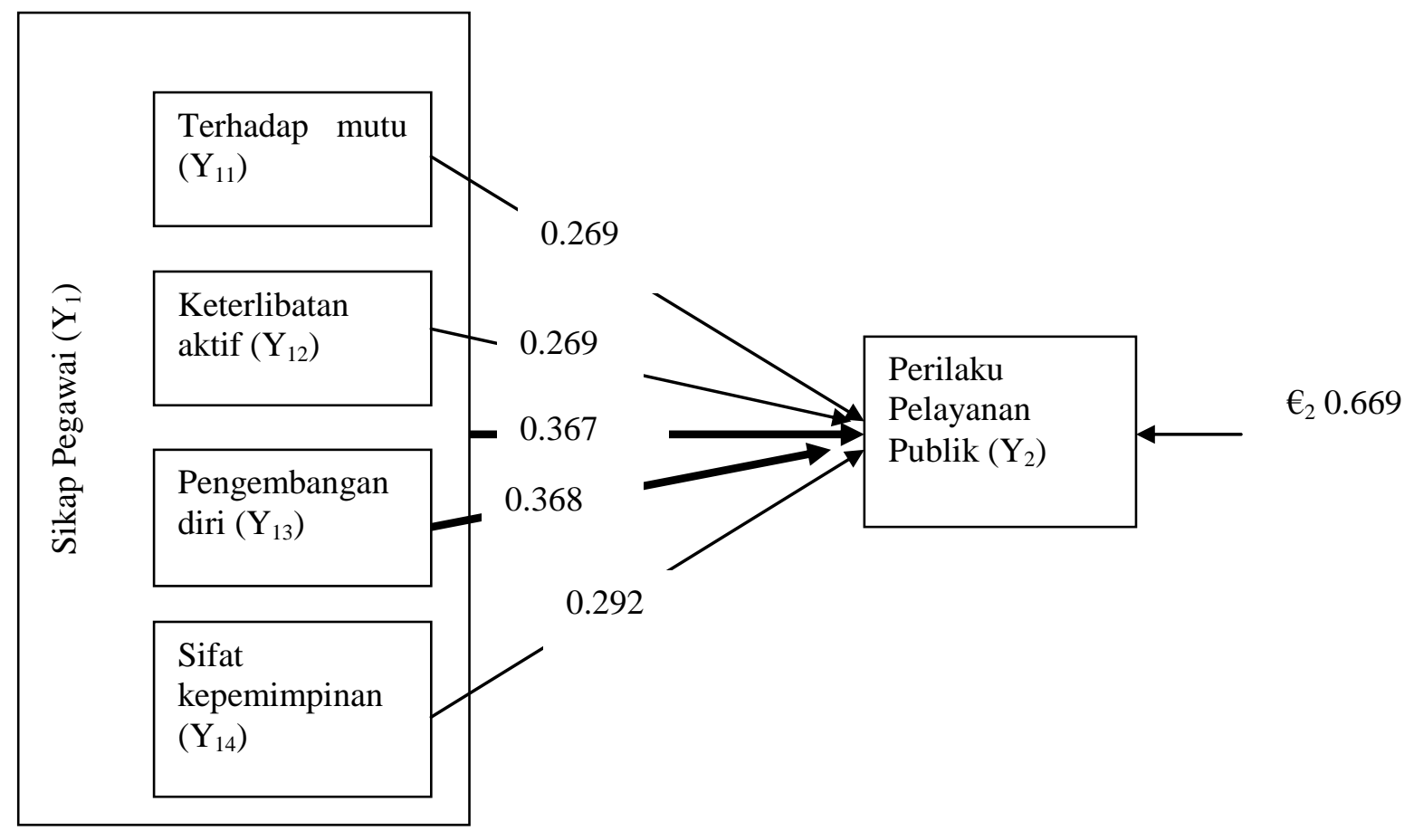

Keterangan: $\mathrm{n}$; 96; nilai $\alpha: 0.01$

Gambar 1. Pengaruh Sikap Pegawai terhadap Perilaku Pelayanan Publik

pada pelayanan publik yang responsif, handal dan memiliki etika pelayanan yang diharapkan. Sedangkan sub peubah bagaimana pegawai menyikapi pengembangan diri, kompetensi dan kapasitasnya untuk meningkatkan mutu pelaksanaan tugas menjadi faktor dominan yang berpengaruh terhadap perilaku pegawai. Pengembangan diri pegawai yang secara terus menerus, dilakukan baik dengan cara mengikuti pendidikan formal yang lebih tinggi maupun dengan mengikuti pendidikan nonformal yang sesuai dengan bidang tugasnya. Pendidikan dengan demikian memberikan pengaruh yang besar terhadap perubahan perilaku seseorang. Temuan ini sejalan dengan Padmowihardjo (1994) yang menyatakan bahwa pendidikan dilaksanakan sebagai upaya mengadakan perubahan perilaku berdasarkan ilmu-ilmu dan atau pengalamanpengalaman yang sudah diakui dan diterima masyarakat. Perubahan perilaku yang ditimbulkan sebagai akibat dari proses pendidikan dapat dilihat dari perubahan pengetahuan, keterampilan dan kebiasaan dalam melakukan sesuatu, dan dalam sikap mental terhadap sesuatu (Slamet, 2003).

Jika dikaitkan hasil temuan penelitian ini dengan kajian Cameron dan Sine (1999) tentang beberapa karakteristik yang membedakan sebuah organisasi memiliki budaya mutu dapat dilihat dari beberapa hal, yakni: adanya efektifitas organisasi yang cukup tinggi, diterapkannya alat untuk mengukur standar mutu, seperti penerapan ISO 9001, memiliki sikap yang positif terhadap cara-cara pengumpulan data, analis dan pemanfaatan data khususnya untuk mengetahui keinginan pelanggan, maka dapat disimpulkan bahwa pegawai di BP2T Kabupaten Sragen maupun BP2T Kabupaten Sidoarjo telah memiliki ciriciri sebagai pegawai yang berbudaya mutu. Selain itu organisasi juga dapat dengan mudah dikenali sebagai organisasi pembelajar (learning organization), diterapkannya koordinasi silang bagi para fungsional, menekankan optimalisasi penggunaan pegawai dan mutu menjadi prioritas organisasi.

Temuan empiris penelitian menunjukkan bahwa perilaku pegawai di kedua daerah 
Jurnal Penyuluhan, Maret 2012 Vol. 8 No.1

penelitian dapat dikatakan telah berbudaya mutu. (1) BP2T Sragen dan Sidoarjo telah menerapkan salah satu alat untuk menerapkan dan mengukur standar mutu, yakni menerapkan SMM ISO 9001 sejak tahun 2002 (Sragen) dan 2003 (Sidoarjo). (2) Mereka memiliki efektifitas yang cukup tinggi terkait dengan kinerja yang dicapainya, yakni jumlah perijinan yang telah dikeluarkan, keterlambatan penyelesaian perijinan yang berada di bawah 5\% . Secara proporsional, satu orang pegawai melayani 197 perijinan per tahun, artinya setiap dua hari sekali sebuah perijinan dapat diselesaikan dengan baik (BP2T Sidoarjo, 2011). (3) Kedua BP2T Baik Sragen maupun Sidoarjo selalu melaksanakan survey untuk mengumpulkan data kepuasan pelanggan atau kepuasan masyarakat, yakni mengukur Indeks Kepuasan Masyarakat (IKM), baik dilakukan sendiri maupun menggunakan pihak ketiga di luar BP2T. BP2T Sragen dan Sidoarjo dengan mudah dikenali sebagai organisasi pembelajar dengan adanya program-program pembelajaran di organisasi yang secara teratur dilaksanakan 1 hingga 3 kali dalam setahun (customer awareness, pengembangan pribadi, dan kegiatan pembelajaran lainnya yang lebih mengarah kepada pengembangan kompetensi pegawai). Selain itu, SDM yang ada dipergunakan secara optimal. BP2T Sragen memiliki 43 pegawai untuk melayani hampir 70 jenis layanan perijinan dan non perijinan, sedangkan Sidoarjo memiliki lebih banyak pegawai (61 orang ) untuk melayani 25 jenis perijinan dengan sistem satu pintu. Mutu pelayanan menjadi perhatian yang tinggi di kedua daerah penelitian dimana kedua pimpinan BP2T selalu mencari jalan atau inovasi untuk bisa memberikan layanan yang terbaik untuk masyarakat dan kepuasan mereka.

Pandangan untuk selalu meningkatkan mutu yang menjadi salah satu parameter budaya mutu terlihat pada pandangan pimpinan BP2T (DS, 47 tahun) untuk selalu melakukan upaya-upaya perbaikan, misalnya dengan visi pelayanan prima yang diwujudkannya dalam pola "tujuh tiga dan delapan empat". Artinya pelayanan yang biasanya dilaksanakan selesai dalam waktu tujuh hari dipangkas menjadi tiga hari, dan pelayanan yang membutuhkan waktu delapan hari dipangkas menjadi empat hari. DS juga membuat terobosan dengan mengadakan pelatihan bahasa asing, khususnya terkait dengan kecenderungan meningkatnya jumlah investor yang berasal dari negara Korea dan Taiwan. Kebijakan tersebut dilakukan untuk semakin menarik minat investor datang di daerahnya. DS juga memperkirakan bahwa Lembaga Swadaya Masyarakat, pengusaha, wartawan media akan menjadi kelompok penekan (pressure group) yang semakin kuat. Pengusaha mempunyai hak untuk memilih dimana ia akan menginvestasikan dananya, dan daerah-daerah di sekitar Sidoarjo seperti Gresik, Surabaya, Pasuruan, Mojokerto adalah saingan Sidoarjo, sehingga penerapan ISO 9001 harus dijaga kesinambungannya. Pimpinan BP2T Sidoarjo (DS,47 tahun) menyatakan bahwa menerapkan ISO tidak murah, tetapi biaya tidak menjadi halangan karena perlu mengubah budaya kerja. Jika budaya mutu ISO 9001 sudah berjalan dan sudah terbiasa, maka mereka yang baru masuk terlibat di organisasi akan mengikuti budaya yang sudah ada tersebut.

Budaya ISO telah dirasakan manfaatnya oleh para pegawai BP2T. Salah seorang pegawai, NB menyatakan adanya keteraturan dalam bekerja serta memberinya banyak waktu karena ia tidak harus mengerjakan berbagai macam pekerjaan yang bukan menjadi bidang kerjanya. Disamping itu, dengan sistem yang ada, ia bisa mengetahui target penyelesaian pekerjaan. Bagi NB tidak jadi masalah jika diperlukan waktu tambahan untuk mengerjakannya. NB menyatakan rasa bangganya dengan bisa bekerja di BP2T yang memiliki budaya kerja yang berbeda dengan unit kerja lainnya di Sidoarjo.

Jika dikaitkan dengan terbentuknya budaya, mulai dari ide-ide, perilaku dan kemudian simbol-simbol, artefaks, benda-benda seni (Koentjaraningrat, 2000), maka perilaku berbudaya mutu yang tergambarkan di dua daerah penelitian telah membentuk budaya mutu di masyarakat. Ide pelayanan yang berbasiskan SMM ISO 9001 yang bertaraf internasional dan diakui perannya, perilaku 
pegawai yang responsif terhadap pelanggan dan masyarakat, serta sarana dan prasarana pelayanan yang telah memperhatikan kebutuhan dan kenyamanan masyarakat adalah bukti telah terjadinya perubahan budaya birokrasi yang lamban, tidak responsif dan tidak kredibel menjadi budaya birokrasi yang menjadikan masyarakat sebagai pelanggan utamanya.

\section{Kesimpulan}

Sikap pegawai BP2T Kabupaten Sragen dan BP2T Kabupaten Sidoarjo terhadap mutu termasuk ke dalam kategori tinggi. Sedangkan jika dilihat dari parameter pendukung sikap, maka pegawai BP2T Kabupaten Sidoarjo memandang mutu lebih tinggi daripada pegawai BP2T Kabupaten Sidoarjo. Ini terlihat nyata di lapangan bagaimana sertifikasi ISO 9001 di Sidoarjo masih tetap dapat dipertahankan keberlangsungannya. Sedangkan sikap pegawai terhadap pengembangan diri di BP2T Kabupaten Sragen lebih tinggi daripada sikap pegawai BP2T Kabupaten Sidoarjo. Hal ini dimungkinkan dari intensitas dan antusiasme pegawai BP2T Kabupaten Sragen yang melanjutkan pendidikan formalnya ke jenjang yang lebih tinggi.

Sikap pegawai BP2T yang memandang positif dan termasuk pada kategori yang tinggi (BP2T Kabupaten Sragen) dan sangat tinggi (BP2T Kabupaten Sidoarjo) telah berimplikasi kepada perilaku pelayanan pegawai terhadap masyarakat. Perilaku pelayanan pegawai di dua daerah penelitian termasuk kedalam kategori yang sangat tinggi. Artinya, pegawai telah memiliki perilaku yang diharapkan, yakni berorientasi kepada kualitas pelayanan yang diharapkan masyarakat. Sikap pegawai terhadap mutu berpengaruh positif dan nyata terhadap perilaku pegawai di dalam pelayanan yang responsif, handal dan memiliki etika kepada masyarakat. Sikap pegawai yang positif pada pengembangan diri secara berkelanjutan menjadi faktor dominan yang berpengaruh terhadap perilaku pegawai terhadap pelayanan publik. Budaya mutu terbentuk di dua daerah penelitian tersebut sebagai dampak dari diterapkannya SMM ISO 9001 yang telah berjalan bertahun-tahun lamanya.

\section{Daftar Pustaka}

Ahmad, Zakaria. 2001. Reengineering Public Services Through ISO 9001. Asian Review of Public Administration. Hal. 108-119.

Ahmadi, Abu.H. 2007. Psikologi Sosial. Jakarta:Rineka Cipta.

Cameron, Kim, dan Wesley Sine. 1999. A Framework for Organizational Quality Culture. QM Journal, Vol. 99 No. 6.

Chu, Pin-Yu. et al. 2001. ISO 9000 and Public Organizations in Taiwan: Organizational Differences in Implementation Practices with Organization Size, Unionization and Service Types. Public Organization Review: A Global Journal (1). hlm. 391413.

Dwiyanto, Agus, 2003. Reformasi Tata Pemerintahan dan Otonomi Daerah. Jogjakarta: Pusat Studi Kependudukan dan Kebijakan, UGM.

Dwiyanto, Agus, 2010. Reformasi Tata Pemerintahan dan Otonomi Daerah. Jogjakarta: Gadjah Mada University Press.

Faozan, Haris, (2003), Peran Birokrasi, Manajemen Kebijakan dan Eksistensi Pelayanan Publik. Jakarta: Lembaga Administrasi Negara.

Garvin, D.A., 1988. Managing Quality: The Strategic and Competitive Edge. New York:Free Press.

Gizzi, Cindan, (tanpa tahun). Building a Quality Culture in Public Health:

lessons learned from a Fellow MLC State: Washington. www.iphionline.org/ vertical/sites (di down load 4/5/12).

Hafni, 2004. Pengaruh ISO 9001:2000 terhadap Produktivitas Kerja Karyawan Rumah Sakit "X" di Medan [skripsi]. Sekolah Pascasarjana-USU, Medan

Harmantyo, Djoko. 2007. Pemekaran Daerah dan Konflik Keuangan Kebijakan Otonomi Daerah dan Implementasinya 
Jurnal Penyuluhan, Maret 2012 Vol. 8 No.1

di Indonesia. Makara Sains, vol. 11, no. 1, April 2001. Hlm. 16-22

Hoyle, David. 2010. ISO 9000 Quality System Handbook, 6th ed. Oxford: Butterworth-Heinemann

Kartono, Kartini. 2006. Pemimpin dan Kepemimpinan. Jakarta: Raja Grafindo Persada.

Kementerian Pendayagunaan Aparatur Negara, 2006. Pedoman Pelaksanaan Pelayanan Publik, Kiat dan Terobosan Kabupaten/Kota

Keputusan Menteri Pendayagunaan Aparatur

Negara tentang Pelayanan Publik, Nomor: 63/Kep/M.PAN/7/2003

Koo, Hannah; L.C. Koo dan Fredrick K.C. Tao. 1998. Analysing Employee Attitudes Towards ISO Certification. Managing Service Quality, Vol. 8, No.5, hlm. 312-319.

Munhum, Prabha Ramscook, Soolakshna D, Kukea,Bhiwajee Pernjoo Naido.2010. Service Quality in the Public Service. International Journal of Management and Marketing Research, Vol. 3 No.1. hlm. 37-47.

Nasution, M.N. 2005. Manajemen Mutu Terpadu (Total Quality Management). Bogor: Ghalia Indonesia .

Ollila, A. 1995. Quality Improvement Through ISO 9000 Standard. [dissertation]. Helsinki University of Technology. Espoo, Finland.

Osborne, David, Ted Gaebler. 1992. Mewirausahakan Birokrasi. Diterjemahkan dari Reinventing Government. Jakarta : PPM
Padmowihardjo, Soedijanto. 1994. Materi Pokok Psikologi Belajar Mengajar. Jakarta: Universitas Terbuka.

Priyono, Agung. 2006. Pelayanan Satu Atap sebagai Strategi Pelayanan Prima di Era Otonomi Daerah. Jurnal Spirit Publik, Vo. 2. Nomor 2. hlm. 67-74

Riduwan, MBA. 2009. Skala Pengukuran Variabel-Variabel Penelitian. Bandung: Alfabeta

Rustandi,Yudi. 2010. Identifikasi Perilaku Santri pada Pengembangan Kompetensi AGribisnis (Studi Pemberdayaan Santri Pondok Pesantren Al- Itifaq. [Skripsi], Sekolah Pascasarjana Universitas Sebelas Maret, Surakarta.

Slamet, Margono. 2003. Memantapkan Penyuluhan Pertanian di Indonesia. Dalam Membentuk Pola Perilaku Manusia Pembangunan. Penyunting Ida Yustina dan Adjat Sudrajat. IPB Press. Bogor.

Sigh, Prakash and Manshour Nahra. 2006. ISO 9000 in the Public Sector: A Succesful Case from Australia. The TQM Magazine, Vol. 18 No.2, hal. 131142

Sutoyo. 2006. Analisis Pengaruh Penerapan Sistem Manajemen Mutu ISO 9001:2000 terhadap Kinerja Karyawan pada PT. Brantas Abipraya Wilayah I Medan. [Tesis]. Sekolah PascasarjanaUniversitas Sumatra Utara, Medan

Warnaen, Suwarsih. 2002. Stereotip Etnis dalam Masyarakat Multi Etnis. Jakarta: Mata Bangsa

Widodo, Tri Putro.2005. Autisme Birokrasi. Jurnal Sarathi, Vol. 12 No. 2. 